\title{
LNG Terminal Development Facilities in Latvia Basing on the Experience of Other States
}

\author{
Dr.oec. Astrida Rijkure \\ Latvian Maritime academy, Riga, Latvia \\ E-mail: astrida.rijkure@gmail.com
}

Received 13 February 2017; accepted 24 March 2017

\begin{abstract}
Liquefaction of natural gas provides great opportunities for its trade and transportation, making it cost-effective and accessible to places where installing pipelines is impossible or economically unjustified. Liquefied natural gas also opens opportunities for market diversification, if the region is tied to one supplier, as it is in Latvia, with potential positive effects on both the market price and the region's energy security. In view of the growing LNG trade and transport industry, the article studies the possibility to import natural gas in liquefied form. Neither Latvia or Estonia has largescale facilities to import natural gas in liquefied form. The only natural gas sources are natural gas imported from Russia through piping. Latvia and Estonia can import and store liquefied petroleum gas (LPG), which is the drained by-product of natural gas extraction and liquefaction process, ethane and butane. Lithuania has the only LNG import terminal in the Baltic countries. The aim of the study is to understand the feasibility and validity of constructing a LNG terminal in Latvian territory based on the Lithuanian experience.
\end{abstract}

Keywords: LNG, LNG bunkering, natural gas imports, gas commercial and transportation industries.

JEL Classification: P28, Q43, Q57.

Conference topic: LNG terminal development facilities in Latvia basing on the experience of other states (e.g.) Sustainable Economics Development.

\section{Introduction}

Lately, world energy policy has experienced many strokes resulting in energy market changes, and liquefied natural gas (hereinafter - LNG) gains a more substantial role in these markets. Due to its properties of reduced emission during combustion process and vast reserves, LNG becomes a frequent response to energy sourcing issues. In Latvia, it is important to evaluate the possibilities for building LNG terminal in one of the Latvia's small or large ports, as liquification of natural gas provides great opportunities for its trade and transportation, thus making it economically beneficial and accessible in places where building pipelines is not possible or economically beneficial. LNG also provides opportunities for gas market diversification in regions depending on a single supplier, like Latvia. This diversification will potentially have a positive impact on both market price and region`s energetic security. One of the main tasks in this study is to analyse the possibilities for building a LNG terminal by assessing the factors like location, potential connection to gas storage facilities, terminal type, capital costs, maintenance costs, capacity, etc. Emphasis will be on researching the existing terminals, especially the LNG terminal in Klaipeda that was built in 2015. Assessment of possibilities and validity for building a LNG terminal will be advanced as the key problem by evaluating the existing market situation and terminal in Klaipeda port. Placement of LNG import terminal in Latvia is the subject of this study. Liquefied natural gas terminal is the object of this study. Hypothesis. The most effective placement for LNG terminal in Latvia is in Skulte port as this port is the closest to Inčukalns Underground Gas Storage Facility. Goal of this study is to define the most appropriate location for LNG import terminal in Latvia and to provide conclusions and proposals on validity of building such terminal in Latvia by assessing experience in other countries and calculating costs for terminal and imported LNG. To reach the goal of this study, the following tasks have been set: to assess technical possibilities and technologies for LNG transportation; to analyse current situation in LNG trade and transport market; to study and compare natural gas infrastructure and potential storage facilities in Latvia; to analyse natural gas consumption trends in the Baltic States; to assess potential and define the most eligible location for LNG import terminal in Latvia; to analyse costs of the terminal and imported LNG. Research methods. Methods of literature and statistics analysis, linear trend forcasting, port performance:an economics perspective and expert survey were appliedduring the research.

(C) 2017 A. Rijkure. Published by VGTU Press. This is an open-access article distributed under the terms of the Creative Commons Attribution (CC BY 4.0) License, which permits unrestricted use, distribution, and reproduction in any medium, provided the original author and source are credited. 


\section{General Requirements}

Like Latvia, also other countries and regions do not have their own gas fields. Often gas fields are in hardly accessible locations or far from end consumers, and frequently piping cannot be used as a solution for transporting natural gas to these end consumers. Instead, ships are used, so gas is liquefied to provide that transportation is more cost-efficient. During this process, gas decreases approximately 600 times in volume, and colourless, non-toxic liquid is formed that is suitable for transportation (Marineinsight 2016). Main condition for gas storage is to maintain it cold, therefore storage reservoirs should be well isolated. Land storage reservoirs have double wall construction with efficient layer of isolation between them. Low temperature is crucial so gas does not cool down and evaporate. If LNG steam is not ventilated out of the reservoir or recycled back into liquid, the temperature and pressure will continue to increase within the reservoir. It is possible to use the originating steam for producing power in the terminal or, in case of ship transportation, to use the gas resulting in evaporation process as the ship fuel (European Comission 2015). Nevertheless, even the best isolating materials cannot fully stop the LNG from warming up, therefore LNG reservoirs both on the shore and in ships use the phenomenon called "automatic-refrigeration". It can preserve LNG in a practically permanent temperature of $-162{ }^{\circ} \mathrm{C}$ if constant pressure in reservoirs is maintained. This process is based on LNG steam pumping and is used in producing power or for reliquefication and returning it to the reservoir (European Comission 2016). There are several types of LNG terminals, but basically, they all have the same operating principle - reception of incoming LNG tankers, LNG storage and regasification: land LNG import terminal, coastal LNG import terminal, floating storage and regasification import terminal and gas import terminal with a possibility to accept a regasified natural gas from LNG tanker:

1. Placement and infrastructure of a land LNG terminal complies with the conventional liquid cargo import terminals. A typical land LNG import terminal has a pier that can accept LNG tankers and that can connect the terminal with incoming tankers. Further away from the pier, terminal has LNG storage reservoirs. Land LNG terminal requires large land area and possibility to build special piers to accept liquefied natural gas from LNG tankers (Marinelog 2007);

2. Coastal LNG terminals can be floating, static or gravity-based. Coastal terminals are good alternative if there is limited access or limited site available for a land terminal. Floating terminals can have lower capital costs, especially if there is no need for LNG storage. Building such terminal is very time-consuming and expensive process (LNG world news 2016);

3. Floating import terminal for storing and regasification of LNG is a compact solution. It does not require building a substantial infrastructure, as all operations like acceptance of LNG and its regasification can be done on the terminal itself. Floating import terminal is permanently towed to the specially built pier and connected to the central gas distribution network. Floating import terminal can accept LNG from other LNG tankers and store it in its storage reservoirs. Terminal in Lithuania is an example of such a floating terminal. It is permanently towed at a specially built pier in Klaipeda port, it can store $170000 \mathrm{~m}^{3}$ and its yearly capacity is 4 billion $\mathrm{m}^{3}$. Considering that there are already several floating import terminals globally, it is possible to save time and resources by choosing an existing terminal design (BIMCO 2010);

4. Gas import terminal with a possibility to accept regasified natural gas from LNG tankers has an underwater buoy that can connect to LNG tankers. Already regasified natural gas is transferred to the terminal that can be further transported through pipeline to the storage facilities or directly to the gas supply network. Building and construction of terminal is relatively simple, but it depends on the supplying LNG tanker specification. Tankers that supply this type of terminal, must have the regasification equipment and ability to connect to the underwater reception buoy (Hovland 2014).

Liquefied natural gas is transported by LNG tankers anywhere it can be imported. Duration of handling depends on the capacity of import and export facilities.

Total LNG export in 2015 was 244,8 million tons being the highest throughout the history. There were 17 active exporting countries in 2015, Catar being the largest with $31,8 \%$ of the total market (European Comission 2016).

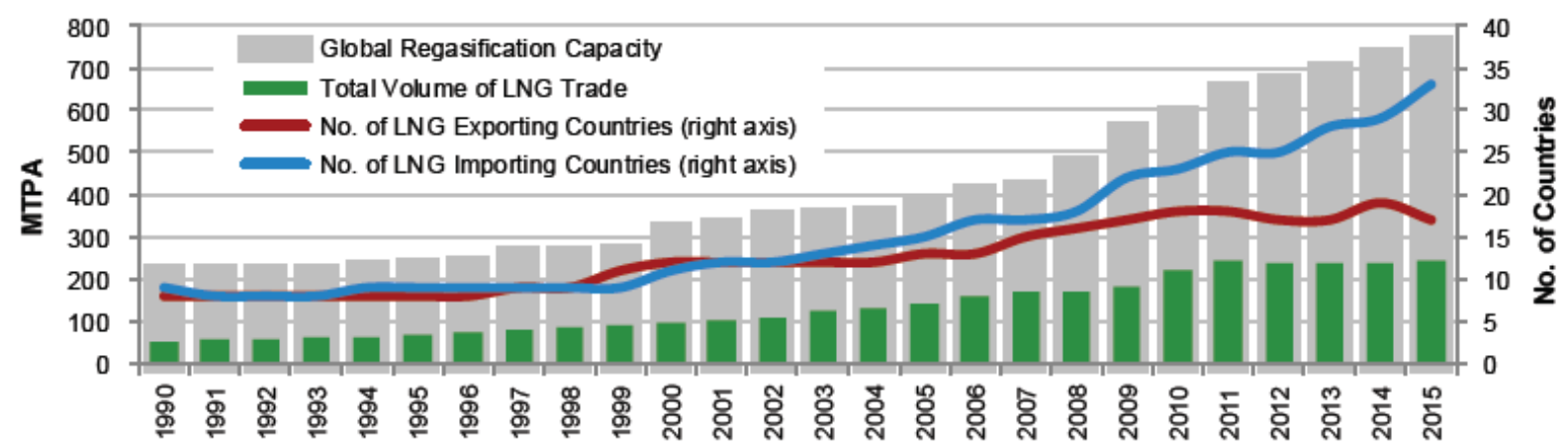

Fig. 1. LNG Trade Volumes, 1990-2015 (Source: International Gas Union 2016) 
Europe imported 37,5 million tons of LNG in 2015 that makes it the second largest importing region after Asian part of the Pacific, which imported 139,8 million tons, mostly due to Japan. As the largest LNG importing countries (Japan, South Korea and China) geographically are in regions where building of gas pipelines is difficult, their dependence on LNG import is very high. Additionally, number of industries that are intending to or already are using LNG seafaring, for example - is increasing. LNG demand is estimated as stable, and there are no indications for significant decrease in demand.

Total number of import terminals with regasification abilities reached 108 in 2015 providing total regasification capacity of up to 757 million tons per year. These terminals often provide both LNG acceptance and ship bunkering operations. LNG bunkering is especially important for countries that are in emission control zones where demand for LNG continues to grow as ship owners equip their fleet with ability to use LNG as fuel (International Gas Union 2016).

Overall trend in global LNG markets indicates a rapid development of the industry. Undoubtedly, one of the driving forces of natural gas market is its relatively small emissions and vast reserves. Considering both current and historical situation, market is in a growth phase, as new exporters and importers are joining constantly. New market players and increasing choice of technological solutions provide new opportunities, and prices both for LNG and technologies are forced down. Price decrease is only natural and, by developing existing infrastructure and adding new, level of competitiveness will only increase that will result in another factor affecting the price decrease (European Comission 2008).

Neither Latvia, nor Estonia has vast opportunities to import natural gas in liquefied form. Their only natural gas source is natural gas imported from Russia through pipelines. Latvia and Estonia can import and store liquefied natural gas (propane gas) - the pumped-out by-product during extraction and liquification process of natural gas, ethane and butane - in terminals like "Latvijas Propāna Gāze" that can store up to $7600 \mathrm{~m}^{3}$ of propane gas and accept tankers with draught up to 6,9 m (Latvian Propan Gas 2017).

Lithuania is the only one among the Baltic States that has LNG import terminal. In 2012, Lithuania signed a longterm lease agreement with "Hoegh LNG" providing a buy-back of the floating LNG storage and regasification terminal at the end of the lease term. Terminal is managed by AB "Klaipedos nafta". Import terminal "Independence" was built in Korean shipyard "Hyundai Heavy Industries Co., Ltd" and completed in 2014. Main reason for acquiring this terminal was mitigation of dependence on gas supplies from Russia through pipelines and diversification of gas market. Import terminal "Independence" can store $170000 \mathrm{~m}^{3}$ of LNG in its four reservoirs, and its nominal import capacity is 4 billion $\mathrm{m}^{3}$ yearly. Terminal has a long-term connection to one pier, and cargo is accepted with ship-to-ship handling. Import terminal can accept ships with LNG load capacity of up to $160000 \mathrm{~m}^{3}$, and guaranteed pier depth is $14,5 \mathrm{~m}$. Pipeline supply system to main Lithuanian gas pipeline network was built. It is possible to download and pump the regasified natural gas into pipeline systems with a 54-bar pressure (European Comission 2015).

According to the author of this study, terminal in Lithuania is a significant and current example for developing the import terminal in Latvia. Assessing potential extent of costs and expenditure items, it is possible to adjust these items for potential terminal in Latvia.

Lithuania chose a floating LNG storage and regasification ship as a solution for LNG import terminal with a lease term of 10 years with a buy-out option from the ship owners at the end of the agreement. During these 10 years, Lithuania will pay approximately EUR 61,45 million yearly which might reach the total amount of EUR 614,5 million. Costs include also maintenance and crew (Klaipedos Nafta Terminalas 2013). Estimations indicate that ship construction costs are approximately EUR 308 million (USD 330 million) (Matulionis 2013). Pier construction costs were approximately EUR 34,77 million, and $18 \mathrm{~km}$ long gas pipeline connecting terminal to Lithuanian gas distribution network costed approximately EUR 35,13 million.

Table 1. Lithuanian LNG terminal cost items (created by author using Klaipedos nafta 2014)

\begin{tabular}{c|c}
\hline Terminal cost items & Total EUR million \\
\hline Infrastructure and planning costs & $\mathbf{1 3 0}$ \\
\hline incl. pier construction & 34.77 \\
\hline Construction of the pipeline connection & 35.13 \\
\hline Other infrastructure costs & 60.1 \\
\hline Terminal rent (per year) & $\mathbf{6 1 . 4 5}$ \\
10 years & $\sim 614.5$ \\
\hline Terminal maintenance (LNG extra charge) & $\mathbf{8 3 . 9 7}$ \\
\hline Guarantee deposit at FSRU & $\mathbf{4 3}$ \\
\hline
\end{tabular}

Considering the high lease costs, Lithuania has tried to negotiate with the ship owners on early terminal buy-out to distribute the purchase costs in a longer term thus reducing yearly burden. Additionally, this model could help with 
LNG competitiveness regarding price. According to latest available information, negotiations were not successful and ship owners "Hoegh LNG" are not interested in early buy-out. It is worth mentioning that in September 2015, "Hoegh LNG" sold the same type of ship to their partners for approximately EUR 344 million. This price corresponds with the approximate price of the ship "Independence" mentioned above and may serve as a current indicator (LNG world news 2016).

Considering that, except for Lithuania, market demand in Latvia and Estonia is fully met by natural gas supplies from Russia through pipelines, and maximal capacity, due to Inčukalns Underground Gas Storage Facility, is not reached, the question is whether there is a need for such a major infrastructure project. One of the motivating factors for building import LNG terminal is natural gas prices in Latvia. Moreover, there are other risks related to one supplier's monopoly in the market:

- Supply reliability - although there have not been any problems with natural gas supplies so far, dependence on one supplier is crucial as there are no other facilities for natural gas import. Gas supply is subjected to both political and technical aspects, and supply interruption under any circumstances may substantially paralyze energy market in Latvia.

- Insufficient competition - when there is only one company operating in the market, it is not affected by competition. Considering that competition is the key factor for providing positive contribution to quality of services and to pricing, it may be said with assurance that the lack of competition may limit market development.

Besides the above-mentioned supply and political risks, single supplier`s monopoly leads to unfavourable terms for gas purchase. To mitigate this market inequality, Latvia needed fundamental changes in Energy Law that provided special status for AS "Latvijas Gāze". Acknowledging the need for changes in the market, the Latvian Parliament passed amendments to the Energy Law on February 11, 2016 providing natural gas market liberalization. New amendments provide that natural gas transmission and storage must be separated from distribution and trade, i.e., AS "Latvijas Gāze" must be demerged into two companies until April 3, 2017. After this date, natural gas market will experience significant changes as it will be opened to any supplier. Open market will ensure competition in the natural gas market, and, by gaining access to gas distribution networks in Latvia, there will be vast opportunities to attract new companies or investors, which is essential for gas supply reliability and for energy sector in general. In addition to supply reliability, it is a big step towards potential alternative gas supplies, i.e., LNG import terminal that, in turn, might be a step closer to decrease in natural gas purchase prices.

Within the Baltic States, there are two categories of natural gas prices - imported pipeline gas from Russia and LNG imported in Lithuania. Latvia was paying the highest price for pipeline gas in the first quarter of 2016, i.e., 21,86 EUR/MWh, whilst pipeline gas prices in Lithuania and Estonia were 20,11 and 18,21 EUR/MWh respectively. Price for LNG imported in Lithuania was 21,96 EUR/MWh. Data for this quarter indicate that prices for imported LNG have a potential to compete with the prices for pipeline gas (Matulionis 2013). It should be noted that in 2014, Lithuania managed to negotiate the gas import price agreement with the Russian gas company "Gazprom" reducing the price of the imported gas by at least $20 \%$, which was achieved, to a large extent, due to negotiations freedom resulting from planned supply of LNG import terminal to Klaipeda. It shows the positive impact of the competition on natural gas prices (Öresundskraft AB 2016).

Considering that there is a SOx control zone determined by IMO in the Baltic Sea, ship owners are more and more concerned how to ensure that ships and their emissions comply with the provisions set by IMO. One answer is LNG and above-mentioned gas filling stations in ports within TEN-T network. Currently, Klaipeda port is fully able to provide LNG bunkering due to its LNG import terminal (European Commission 2015).

Considering these policies by European Commission, placing terminal in one of the ports in Latvia would have a higher international significance and would align with the EU policy. Such placement could also qualify for EU financing available for project implementation. Regardless, placing terminal in Riga or close to Inčukalns Underground Gas Storage Facility, in Skulte could bring different positive features.

\section{Freeport of Riga}

Freeport of Riga has reserved an area for building the LNG terminal in its territory. As the draught of most LNG tankers does not exceed $12 \mathrm{~m}$ and the draught of conventional tankers does not exceed $11 \mathrm{~m}$, Riga port is suitable for accepting such tankers. Regardless that dredging will be finished until 2018, current ship canals provide a safe access to the port. Maximum depth in Riga port is $16 \mathrm{~m}$, and after dredging it is planned to deepen it up to 17-17,5 m. Riga has an extensive infrastructure for natural gas distribution and supply, and $70 \%$ of the total gas consumption in Latvia is consumed in Riga region. Additionally, Riga is close to Inčukalns Underground Gas Storage Facility, approximately $60 \mathrm{~km}$ away, that would allow for an effective connection and reduced volumes to be stored. Riga's advantage is a vast number of gas consumers, but disadvantage - significant restrictions for building transmission pipelines within the city. Considering that there is already a LNG terminal in Klaipeda, its operations and opportunities may potentially overlap with any LNG terminal assessed in Latvia. Assuming that the gas consumption stays at the current level, partial use of terminal's capacity may increase the costs of LNG import and thus reduce or fully eliminate the competitiveness of the terminal. 


\section{Skulte port}

Skulte port is the closest to Inčukalns Underground Gas Storage Facility. It would be possible to connect the potential LNG terminal with Inčukalns Underground Gas Storage Facility through approx. $40 \mathrm{~km}$ long land pipeline and $5 \mathrm{~km}$ long underwater pipeline. There are no significant restrictions for designing pipelines through these territories as there are no densely populated or built-up areas between Skulte and Inčukalns. Both Skulte port and attached sea territories are subjected to freezing in severe winter conditions and to partial freezing with drifting ice in moderate winter conditions that may substantially affect the safety of seafaring and flexibility of LNG supplies. Port is not included in the TEN-T network and therefore is not subjected to priority status eligible for infrastructure buildings within the network, and it has no access to financing available for the development of TEN-T network. The size of Skulte port is not suitable for large ships, its aquatorium is only up to $8,25 \mathrm{~m}$ deep, and maximum permissible draught is $7 \mathrm{~m}$. Maximum permissible ship dimensions limit the possibilities to accept ships in the protected port aquatorium even more - max. ship length is $140 \mathrm{~m}$ and max. width is $15 \mathrm{~m}$. Considering the limited dimensions of Skulte port, it is possible to provide a floating or fixed LNG terminal for accepting and regasification in the area that is connected to the gas storage facilities through underwater and underground pipelines. Location of Skulte port is explicitly suitable for a floating LNG terminal with a direct connection to the gas storage facilities. Considering the gas market liberalisation, current political environment is favourable for developing serious plans regarding terminal. Lithuania with its Klaipeda terminal has mitigated the Baltic states' dependence on Russia, but the costs of this project is a significant obstacle for effective economic activities. Klaipeda is placed in the area that historically is a gas importer, not exporter, and its full integration in the Baltic states' gas distribution network requires large investments; also, storing gas in a liquefied form requires significant costs. Additionally, until the opening of the gas market in Latvia, there is a problem of accessing the gas distribution network in the territory of Latvia. Therefore, LNG terminal in Skulte will allow to increase the reliability of the Latvian energy market that may help in negotiations with "Gazprom" on future pipeline gas prices, as shows the positive Lithuanian experience.

- When joining the open market, several import possibilities are essential for increasing competition. Having a LNG terminal in Latvia, market would be opened to gas import from all over the world, and the price would not be dictated by the interests of a single monopolistic company, although, due to Klaipeda terminal, the Baltic gas market becomes saturated with offers. Technological possibilities allow higher consumption, but, according to trends during last years, gas consumption in the Baltics is decreasing. Situation with excessive supply capacity may change due to new connections: Estonia-Finland, "Baltic Connector" and Poland-Lithuania, "Gas Interconector". Both projects are planned as two-way gas pipelines connecting the Baltic region and Finland to the rest of Europe. Both projects should be completed until 2019 (European Commission 2015). These connections may significantly influence demand and supply and, considering the central location of Inčukalns Underground Gas Storage Facility, it is a god opportunity to implement LNG terminal in Skulte as part of the new gas distribution scheme. Unlike in Klaipeda LNG terminal, the proposed LNG terminal in Skulte has no minimum import volumes to provide effective and more flexible operation.

- As there is no existing LNG import terminal in Latvia, it is hard to estimate the numbers of free workforce available to operate the terminal immediately, or is there any workforce at all. Training period will be a must for acquiring workforce to ensure the terminal operations. Necessity to recruit foreign experts with experience in LNG import at the initial stage cannot be excluded.

- By providing access to Inčukalns Underground Gas Storage Facility, a connection to the gas distribution network in the whole Baltics would be ensured, thus no additional technical solutions for supplying gas to its end consumers would be needed. Technologies necessary for building the terminal are available, and different designs of LNG import terminals are operating thus providing access to safe and tested technologies.

Basing on examples of existing LNG import terminals and pipeline infrastructure development projects, it is possible to calculate preliminary costs for Skulte terminal. Knowing the average costs per km in Klaipeda terminal $(1,55$ million EUR $/ \mathrm{km})$ and average deviation, as there are incompliances in project dimensions, preliminary costs for connection Skulte-Inčukalns Underground Gas Storage Facility are estimated as 1,89 million EUR/km resulting in total approximate costs for building the pipeline connection in the amount of approx. EUR 85 million. Considering the approximate costs for import terminal and connection, the cost of capital for building the LNG import terminal in Skulte is estimated in the amount of EUR 179 million. Considering that cost of capital for Klaipeda LNG terminal is approx. EUR 130 million, and, for realistic comparison of the first year of operations, the FSRU ship lease in the amount of EUR 61,45 million should be added, the import terminal would be much cheaper for LNG import, even regardless savings on storage costs.

Basing on Lithuanian example and assessing the optimistic and pessimistic projections, it is possible to forecast how the gas market in Latvia could change after the LNG terminal is implemented. Projection scenarios will use the latest available gas tariff data, disregarding fluctuations throughout the year.

The optimistic scenario projects that, after the terminal is built, pipeline gas purchase prices, currently $0,21 \mathrm{EUR} / \mathrm{m}^{3}$, could decrease by $20 \%$ to $0,168 \mathrm{EUR} / \mathrm{m}^{3}$. Basing on gas consumption in Latvia in 2015,1324 million $\mathrm{m}^{3}$ are set as a base unit for the year when gas price decrease would be reached. Due to import terminal, total costs for 
gas purchase would be EUR 222,432 million resulting in total savings of EUR 55,60 million. Surely, an empty, nonoperating import terminal cannot provide sufficient competition in a long run and have a long-term positive effect on gas prices. Considering that the proposed LNG import terminal has no additional storage costs that would equal the current costs in Inčukalns Underground Gas Storage Facility, this component will not be included in the price calculation as an additional item. Optimistic projections show that, initially, price of imported LNG per MWh might reach the price of Norwegian LNG supplies to Lithuania that on the lowest speculative level is $16 \mathrm{EUR} / \mathrm{MWh}$. (Standards of $1 \mathrm{~m}^{3}=10,4 \mathrm{kWh}$ set in Lithuania are used as a convergence example). Considering the gas consumption un forecasted prices, total costs for imported LNG would reach EUR 220,32 million that would equal savings of EUR 2,112 million against the optimistic pipeline gas purchase prices, meaning that the LNG terminal is competitive and might be more beneficial in gas procurements in case of optimistic gas pricing.

Pessimistic scenario projects that gas purchase price stays constant at the mark of $0,21 \mathrm{EUR} / \mathrm{m}^{3}$ resulting in total yearly base cost of EUR 278,04 million. LNG import price is set as 20 EUR/MWh, and total LNG purchase costs would reach EUR 275,4 million that creates even bigger gap between LNG and pipeline gas than in the optimistic scenario, and would reach EUR 2,640 million.

According to the author, the project of LNG import terminal has prospects and great chance for positive changes both in natural gas procurements and stabilization of energetic reliability.

LNG terminal in Skulte would be located in a coastal zone approx. 2,5 km north-west from Skulte port, therefore it would have a minimal impact on the port, existing industrial objects and local inhabitants. To avoid coastal populated areas, it is planned to build a 5,2 km long underwater pipeline. Next would be a $34 \mathrm{~km}$ long underground pipeline with the end connection to Inčukalns Underground Gas Storage Facility. LNG terminal in Skulte would be substantially cheaper than the existing Klaipeda terminal thus providing lower prices to consumers in the Baltics. $70-80 \%$ of the total costs would be construction of LNG storage, but LNG terminal in Skulte, unlike Klaipeda terminal, does not need a storage. Instead, a $34 \mathrm{~km}$ long underground pipeline to Inčukalns Underground Gas Storage Facility would be built. Total project costs are estimated in the amount of EUR 150 million. Capacity of LNG terminal in Skulte is planned to be 4,7 billion $\mathrm{m}^{3}$ /yearly. This capacity is equivalent to the existing capacity in Klaipeda terminal.

Applying quantitative methods is part of the decision-making process. Here, we speak only about the quantitative side of a decision, as making economic decisions is a complicated and versatile process including not only quantity, but also quality. Quality is based on specific knowledge, experience and even intuition, as well as on acquiring and using versatile information in decision-making. When deciding on whether to implement a specific project, a complex body of methods should be used.

Economic analysis is not sufficient to decide on implementing LNG terminal in Latvia, and investment efficiency calculations should be performed. To assess the investment efficiency of the project, calculations were based on resource and profit formulas by scientist (Talley 2007).

A port's effectiveness operating objective function includes the demand function for throughput. A port's throughput demand function represents the relationship between the port throughput demanded by its users and the generalized port price (per unit of throughput) incurred by these users, i.e.:

$$
P T=h(G P)
$$

where

$$
G P=P P+O C+I C+S P
$$

PT-port throughput

$G P$ - generalized port price

$P P$ - port price charged

OC-ocean carrier port time price

IC - inland carrier port time price

SP - shipper port time price

The Port Price Charged per unit of throughput represents prices charged by the port for various port services, e.g., wharfage, berthing, cargo handling and wharfage charges. The Ocean Carrier Port Time Price per unit of throughput represents the time-related costs incurred by ocean carriers while their ships are in port, e.g., ship fuel, labour and depreciation costs. The Inland Carrier Port Time Price per unit of throughput represents the time-related costs incurred by inland (rail and truck) carriers while their vehicles are in port, e.g., vehicle fuel, labour and depreciation costs. The Shipper Port Time Price per unit of throughput represents the time related costs incurred by shippers while their shipments are in port, e.g., inventory costs such as insurance, depreciation and obsolescence costs.

If a port seeks to maximize profits, its profit (or effectiveness operating objective) function may be written as:

$$
P R=P P \times P T-M i n C
$$

PR - profit

$P P$ - port price charged

$P T$ - port throughput

MinC - minimum costs 
Substituting the port's throughput demand function and economic cost function into profit function and rewriting, it follows that:

$$
P R=P P \times h(G P)-g(P T)
$$

PR - profit

$P P$ - port price charged

GP - generalized port price

PT-port throughput

As per author, these formulas should be modified to calculate the investment efficiency for the LNG terminal. Author developed her own formula, where:

$$
P I n v=\frac{P P}{I P}-(P T \times G P)
$$

PInv-port terminal investment costs

$P P$ - port price charged

IP - investment payback period

PT-port throughput

GP - generalized port price

This formula suggests that the planned investment payback period should be assessed when calculating investment efficiency. By calculations, a ratio is gained providing the level of investment efficiency.

If,

PInv $\leq 1$, then investment efficiency is satisfactory and, the higher the ratio, the higher the money surplus or return on investment.

PInv $\geq 1$, then investment efficiency is low, and risks should be assessed carefully as it points that the investments will exceed the anticipated gains.

Calculations show that with the investment payback period of 10 years (period equal to buy-out period of the platform), the efficiency ratio is -7.15 for LNG project in Lithuania and -9.15 for LNG project in Latvia. Both ratios are below 1 providing that both projects face risks of losses, and 10-year investments may not pay off, but several factors affecting this ratio should be assessed, e.g., gas price changes, inflation, currency exchange rate fluctuations, etc. Therefore, investment efficiency calculations should be done annually, and stability of return on investment should be assessed.

\section{Conclusions}

This study confirms that opening the market will provide competition and opportunities to attract new companies or investors for gas supplies. Building of LNG import terminal will be a step closer to decreasing gas purchase prices. Basing on Lithuanian example and assessing the optimistic and pessimistic projections, it is possible to forecast how the gas market in Latvia could change after the LNG terminal is implemented. According to the author, the project of LNG import terminal has prospects and great chance for positive changes both in natural gas procurements and stabilization of energetic reliability. Assessing opportunities in Latvian ports, author concludes that the most suitable location for LNG terminal is in Skulte port. Terminal would be located in a coastal zone approx. 2,5 km north-west from Skulte port, therefore it would have a minimal impact on the port, existing industrial objects and local inhabitants. It is planned to build a 5,2 km long underwater pipeline and a $34 \mathrm{~km}$ long underground pipeline with the end connection to Inčukalns Underground Gas Storage Facility. LNG terminal in Skulte would be substantially cheaper than the existing Klaipeda terminal, thus ensuring lower gas prices for consumers in the Baltics. $70-80 \%$ of the total costs would be construction of LNG storage, but LNG terminal in Skulte, unlike Klaipeda terminal, does not need a storage. Instead, a $34 \mathrm{~km}$ long underground pipeline to Inčukalns Underground Gas Storage Facility would be built. Total project costs are estimated in the amount of EUR 150 million. Capacity of LNG terminal in Skulte is planned to be 4,7 billion $\mathrm{m}^{3} /$ yearly. This capacity is equivalent to the existing capacity in Klaipeda terminal. Author developed her own investment efficiency calculation formula to assess whether the investments in the specific development project are costeffective. 


\section{References}

BIMCO. 2010. The Floating Storage Regasification Unit (FSRU) [online], [cited 22 July 2016], p. 5-6. Available from Internet: http://www.marineinsight.com/types-of-ships/what-is-floating-storage-regasification-unit-fsru/

European Comission. 2008. Advice on the Opportunity to Set up an Action Plan for the Promotion of LNG Chain Investments, 2230 [online], [cited 17 November 2016]. Available from Internet: https://ec.europa.eu/energy/sites/ener/files/documents/ 2008_05_lng_facilities_part_2_task_c.pdf

European Comission. 2016. Quarterly report on European Gas Markets [online], Vol. 9, p. 4-6 [cited 13 January 2017]. Available from Internet: https://ec.europa.eu/energy/sites/ener/files/documents/quarterly_report_on_european_gas_markets_ q4_2015-q1_2016.pdf

European Commission. 2015. End of energy isolation in the Baltics: how the Gas Interconnector Poland-Lithuania (GIPL) works [online], [cited 15 October 2016]. Available from Internet: http://europa.eu/rapid/press-release_MEMO-15-5845_en.htm

Hovland, K. M. 2014. Gas Terminal Plans Helped Lithuania Negotiate Lower Price From Gazprom. Available from Internet: http://www.wsj.com/articles/gas-terminal-plans-helped-lithuania-negotiate-lower-price-from-gazprom-1401188154

International Gas Union. 2016. 2016 World LNG Report [online], [cited 20 January 2017]. Available from Internet: http://www.igu.org/news/igu-releases-2016-world-lng-report

Klaipedos Nafta Terminalas. 2013. Liquefied natural gas Terminal News [online], [cited 10 January 2017]. Available from Internet: http://www.portofklaipeda.lt/uploads/sgd/Terminalas\%208_EN.pdf

Klaipedos nafta. 2014. About the LNGT project [online], [cited 21 December 2016]. Available from Internet: http://www.sgd.lt/index.php?id=5\&L=

Latvian Propan Gas. [online], [cited 10.01.2017.]. Available from Internet: http://www.lpg.lv/lv/stividoru-pakalpojumi/stividoruostas-pakalpojumi/

LNG world news. 2016. Hoegh LNG sells FSRU Hoegh Gallant to HMLP [online], [cited 20 January 2017]. Available from Internet: http://www.lngworldnews.com/hoegh-lng-sells-fsru-hoegh-gallant-to-hmlp/

Marineinsight. 2016. What is Floating Storage Regasification Unit (FSRU)? [online], [cited 22 January 2017]. Available from Internet: http://www.marineinsight.com/types-of-ships/what-is-floating-storage-regasification-unit-fsru/

Marinelog. 2007. Neptune LNG gets Deepwater Port License [online], [cited 28 December 2016]. Available from Internet: http://www.marinelog.com/DOCS/NEWSMMVII/2007mar00280.html

Matulionis, T. 2013. LNG Terminal in Lithuania [online], [cited 28 December 2016]. Available from Internet: http://www.gasnaturally.eu/uploads/3._Presentation_for_Gas_Naturally_COMPLETE_AND_FINAL_KLAPEIDOS_NAFT A.pdf

Öresundskraft AB. 2016. LNG in Baltic Sea Ports - Stakeholders Platform [online], [cited 13 January 2017]. Available from Internet: https://www.oresundskraft.se/lng/lng/

Talley, W. K. 2007. Port Performance: an economics perspective, in M. R. Brooks, K. Cullinane (Eds.). Devolution, Port Governance and Port Performance, Vol. 17, p. 499-516. 